\title{
Infrastructure of Cultural Leisure in Consumer Society in Student View: Prospects and Problems of Promotion
}

\section{Infraestructura del ocio cultural en la sociedad de consumo en la visión estudiantil: perspectivas y problemas de promoción}

\author{
Vladimir V. Baranov* \\ Doctor of Education, Professor, Head of the Department of Physical Culture, Orenburg State University, \\ Orenburg, Russia \\ ORCID ID: 0000-0002-9614-0272.
}

Artur M. Allagulov

Doctor of Education, Professor of the Department of Pedagogy and Sociology, Orenburg State Pedagogical University, Orenburg, Russia ORCID ID: 0000-0001-5490-6818.

Vladimir V. Kuznetsov

Doctor of Education, Professor of the Department of the General and Professional Pedagogics, Orenburg State University, Orenburg, Russia ORCID ID: 0000-0002-1267-8834

Oleg V. Khlusyanov

$\mathrm{PhD}$ in Education, Associate Professor of the Department of Physical Education, Vyatka State University, Kirov, Russia ORCID ID: 0000-0003-4237-5161.

\section{Anna M. Yudina}

$\mathrm{PhD}$ in Education, Associate Professor of the Department of Pedagogy, Vladimir State University named after Alexander Grigoryevich and Nikolai Grigoryevich Stoletov, Vladimir, Russia ORCID ID: 0000-0001-5420-6643.

\section{Azat S. Valeev}

Doctor of Education, Associate Professor, Head of the Department of Operation of Transport and Technological Machines and Complexes, Sibay Institute (Branch), Bashkir State University, Sibay, Russia ORCID ID: 0000-0001-7973-2332.

Guzel Kh. Valeyeva

$\mathrm{PhD}$ in Education, Associate Professor of the Department of Theory and Methodology of Teaching Technology, Sibay Institute (Branch), Bashkir State University, Sibay, Russia ORCID ID: 0000-0001-8975-8552.

Received 08-12-20 Revised 09-30-20 Accepted 10-13-20 On line 01-14-21

* Correspondence

Email: fizv@mail.osu.ru
Citation:

Vladimir V. Baranov, Artur M. Allagulov, Vladimir V. Kuznetsov, Oleg V. Khlusyanov, Anna M. Yudina, Azat S. Valeev, Guzel Kh. Valeyeva. (2021) Infrastructure of Cultural Leisure in Consumer Society in Student View: Prospects and Problems of Promotion. Propósitos y Representaciones, 9(SPE1), e1223. Doi: http://dx.doi.org/10.20511/pyr2021.v9nSPE1.e1223 
The formation of the cultural leisure infrastructure structures the modern space in a special way and contributes to the formation of a new leisure sphere of modern society. The cultural leisure industry today is not only and not so much a training field, but a huge segment of the country's leisure market. The purpose of the study is to study the features of the cultural leisure infrastructure and its role in the representation of students. Research methods: as a research method, a questionnaire survey was used as a method of collecting primary information, which allows us to identify various aspects related to students' ideas about the ways and problems associated with spending free time. Research results: the article considers the role of leisure in the consumer society. The features of the development of leisure infrastructure are revealed. The novelty and originality of the study lies in the fact that for the first time the field of leisure is considered in the representation of students. It is revealed that leisure time for students is a criterion for identifying the status of a person, acts, as a social marker of a certain lifestyle, is a sphere of manifestation of different capabilities of an individual. It is determined that leisure is often aimed not so much at enjoying free time, as at filling the consumption of non-working time. For the first time, the reasons for the visiting of students in leisure studios are shown. It is revealed that there is a randomness of choice; the desire to find new meanings; a way of searching for oneself. It is shown that students note the leisure industry as a sector where, for a certain fee, the client buys not only the opportunity to spend time, but also new goals and ways of self-expression. It is determined that today leisure studios are not just a place where classes are held twice a week, but also a well-organized recreational space. Leisure studios are organized in such a way that a person who is engaged in, who is interested in it, feels that he belongs to a certain clan. It is revealed that the leisure industry sells not just services, but mood, and it is the leisure studios organized on this principle that are the most successful in the market of leisure services. From the point of view of students, an important role in the leisure industry is played by the teacher, as a guide to the world of hobbies. It is determined that it is the presence of a teacher that structures training in a special way. Practical significance: The data obtained in this work can be used in marketing research, economic sciences, advertising psychology, as well as for further theoretical development of this issue.

Keywords: student youth, attitude, leisure industry, leisure studios.

\section{Resumen}

La formación de la infraestructura de ocio cultural estructura el espacio moderno de una manera especial y contribuye a la formación de una nueva esfera de ocio de la sociedad moderna. La industria del ocio cultural en la actualidad no es solo ni tanto un campo de formación, sino un gran segmento del mercado del ocio del país. El propósito del estudio es estudiar las características de la infraestructura de ocio cultural y su papel en la representación de los estudiantes. Métodos de investigación: como método de investigación, se utilizó una encuesta por cuestionario como método de recolección de información primaria, que permite identificar diversos aspectos relacionados con las ideas de los estudiantes sobre las formas y problemas asociados con el tiempo libre. Resultados de la investigación: el artículo considera el papel del ocio en la sociedad de consumo. Se revelan las características del desarrollo de la infraestructura de ocio. La novedad y originalidad del estudio radica en que por primera vez se considera el campo del ocio en la representación de los estudiantes. Se revela que el tiempo libre para los estudiantes es un criterio para identificar el estatus de una persona, los actos, como marcador social de un determinado estilo de vida, es una esfera de manifestación de las diferentes capacidades de un individuo. Se determina que el ocio no suele estar dirigido tanto a disfrutar del tiempo libre como a suplir el consumo del tiempo no laboral. Por primera vez, se muestran los motivos de la visita de los estudiantes a los estudios de ocio. Se revela que existe una elección aleatoria; el deseo de encontrar nuevos significados; una forma de buscarse a uno mismo. Se demuestra que los estudiantes perciben la industria del ocio como un sector en el que, por una determinada tarifa, el cliente compra no solo la oportunidad de dedicarle tiempo, sino también nuevos objetivos y formas de autoexpresión. Se determina que hoy en día los estudios de ocio no son solo un lugar donde se imparten clases dos 
veces por semana, sino también un espacio recreativo bien organizado. Los estudios de ocio están organizados de tal manera que una persona que se dedica, que está interesada en ellos, siente que pertenece a un cierto clan. Se revela que la industria del ocio vende no solo servicios, sino también humor, y son los estudios de ocio organizados sobre este principio los que tienen más éxito en el mercado de los servicios de ocio. Desde el punto de vista de los estudiantes, el profesor juega un papel importante en la industria del ocio, como guía del mundo de las aficiones. Se determina que es la presencia de un docente la que estructura la formación de manera especial. Importancia práctica: Los datos obtenidos en este trabajo pueden ser utilizados en investigación de mercados, ciencias económicas, psicología publicitaria, así como para un mayor desarrollo teórico de este tema.

Palabras clave: juventud estudiantil, actitud, industria del ocio, estudios de ocio.

\section{Introduction}

The formation of any society causes attempts to conceptualize it, expressed in various theoretical paradigms. Such concepts, while not covering all the diversity of processes, allow the researcher to focus on a particular type of social relations or institutions (Sartre, 2004; Heidegger, 2003; Veretekhina et al., 2017; Putilina et al., 2019; Bayanova et al., 2019; Zinoviev, 2000). Ignoring other areas allows the researcher to delve deeper into the field of research that interests him/her. The consumer society is thus directly related to the development of the economy, accompanied by economic and technological development and social changes: such as income growth, reduced working hours and increased leisure time; the dilution of the class structure; and the individualization of consumption (Lantsev, 2008; Cherdymova \& Rozanova, 2018; Kuznetsova, 2007; Levi, 2011).

However, while generating a tendency to form a consumer society, capitalism is not synonymous with it. In the early stages of development, it encourages the emergence of such a society only in the wealthiest segments of the population. Thus, it is appropriate to speak of the consumer society as a stage in the development of capitalism. It is worth noting, however, that the economic factor is not the only reason for this trend. We can say that there is no defined framework that characterizes the beginning of the era of consumption, but it is rather a set of criteria, the presence of which symbolizes the consumer society. If the first marker is the appearance of advertising, then the second, no less important element, is the appearance of goods that are not aimed at satisfying the basic needs of a person (Shulga, 2000; Radina \& Shaidakova, 2014; Ritzer, 2011). There are a number of features that characterize a consumer society: the mass production of goods, which is the impetus for consumption; the production and consumption of goods goes beyond the basic needs of the individual. Consumption for the maintenance of an individual's social status is also one of the consequences of expanding production. Researchers are now particularly interested in corporeality (Kogan, 1997; Terekhova, 1983). The development of leisure infrastructure contributes to the formation of a huge layer of completely new leisure services, which are not fully meaningful in the framework of modern Russian society (Akhiezer, 1992; Prudensky, 1972).

It is necessary to analyze the role and place of individual consumption in the processes of formation and reproduction of social structures, which is the central category of consumer society. It is thanks to the analysis of the leisure experience of service providers and consumers that we can conclude about the role and place of leisure infrastructure in the city's leisure industry (Voronova, 1997; Leontiev, 1999; Streltsov, 1991; Surtaev, 2002; Burno, 1989). The consumer society is increasingly undergoing revolutionary changes in the organization of trade and the service sector. Currently, we can say that the focus is shifting from selling things to selling services (Panarin, 1972; Veblen, 2010; Yakovleva, 2011; Cherdymova, 2011). It is important to note that large malls are now not just a place for shopping, but include the entire list of leisure services, which in addition to shops, includes recreation areas, and areas for games with children, as well as fitness clubs or leisure studios. 
Thus, the appearance of a person's free time is the main feature of the new society. The reduction of the working day, the technological revolution-all this gives a person time free of work. However, this time also has a consumer value (Reznichenko et al., 2018). It cannot be truly free, since its freedom is provided for and calculated by the structure of the consumer society. In the traditional sense, time disappears. Leisure appears. Moreover, along with it, ways appear to spend leisure time that cannot be spent outside of the consumption system (Baranova, 2009; Toro, 2014; Marcuse, 2009; Sloterdaik, 2009). Leisure consumption is the central category for the analysis. All the previously mentioned markers of the consumer society are most clearly expressed during the individual's free time. Man is no longer left to himself. Structuring free time is one of the main features of this type of society.

\section{Objectives and Structure of the Study}

Leisure becomes an integral part of the consumer society. This is actively promoted by the appearance of a huge number of leisure services. Thus, the recreation infrastructure in the consumer society occupies one of the most important places.

Within the framework of the study, the following main tasks were set: to analyze the reasons for the coming of people in the studio, related to the peculiarities of leisure activities (to find out whether the motivation changes after a certain time); to identify how the communication space inside the studio is organized for leisure time; to consider how the space around the studios is formed, and how they are included in the formation of new leisure areas; to analyze the leisure industry associated with movements as an economic space and to identify how much these activities are associated with demonstrative consumption.

These are questionnaire questions suggested in the study:

Do you have any hobbies?

Do you visit specialized studios?

What is your passion for the current moment?

Do you have any hobbies related to movement? For example, visiting fitness centers or fitness studios? How long have you been engaged in these activities?

Why did you choose this particular studio?

What do classes in this studio give you?

What were your reasons to start doing fitness and come to the studio? What is fitness for you?

Has your attitude to fitness changed over time? Have the motives of the activity changed?

Do this activity involve buying equipment for classes?

Why did you decide to master this activity in a specialized studio, and not to master the movements yourself independently?

Was there a choice between a fitness club and a dance studio? Why did you choose a dance studio over a fitness club?

How much, in your opinion, is the dance space organized in the city, as opposed to fitness studios? If so, what is it expressed in?

Do you communicate with other clients in the visited group? How close?

Have you made any new friends while visiting the leisure studios?

Does your studio organize events outside of the studio?

In your opinion, is there a fashion for dancing, fitness?

Do you plan to continue spending time in this studio? How do you think the leisure industry will develop in the future?

\section{Features of Students' Ideas about the Leisure Industry}

The leisure industry today is a huge economic sphere. The study found that the price for individual classes was quite comparable to the prices for classes in a fitness club, where in addition to group 
classes twice a week, a number of other opportunities were presented. The students surveyed note that the financial component is singled out by them as the main reason (72\%) for changing the leisure studio to a cheaper one, as well as the temporary termination of the occupation. Respondents highlight in their responses that the pricing policy in most leisure studios does not depend on the direction or teacher $(61 \%)$. Pricing is based on the cost of renting halls and, accordingly, the distance from the city. On average, the price of classes, according to respondents, varies from 800 to 1500 rubles for one or two classes. If the direction requires special equipment and the number of students cannot exceed a certain number of people, then the price of the class increases. The surveyed students note that in general, the leisure industry is impossible without related products for classes (97\%). Thus, economic investment seems inevitable. Although a number of respondents (3\%) indicated that they did not spend any additional funds on the purchase of clothing, in general, the associated expenses were quite significant. Here it is appropriate to say that the purchase of inventory is often associated with the purchase of a new status in the leisure environment. In general, in order to start doing, for example, fitness, no special purchases are required. For training, it is enough to have any sports suit, and use sneakers or even socks as shoes.

According to respondents (79\%), one of the main tasks of a leisure studio is to organize communication between people inside. Here the task is not even to create a friendly atmosphere, but rather a family one. In fact, the most successful are those leisure studios that are organized as sects. There is practically no way to get out of the sect here, because if the client misses a class, a worried teacher calls him/her, telling him/her how poorly the classes are progressing without this person. Perhaps this is the main key to the success of any leisure studio. In addition, accordingly, all the events that take place inside the studio are aimed precisely at unity and unification. Both within the studio and within the dance space, there is a clear hierarchy. Accordingly, there are beginners, there are advanced, there are professionals. Joining the leisure world, a person, of course, wants to take a higher level.

Let us first consider the main reasons for the coming of people in leisure studios. Almost all of the students surveyed, in one way or another, mentioned the randomness of choosing such an occupation (96\%). However, if you try to trace the pattern, it becomes obvious that such an accident is often the result of either competent marketing moves by the leisure studios themselves, distributing flyers or placing ads in magazines, or fashion for dancing in general. Interestingly, the managers of leisure studios also point out as the main reason for coming to leisure studios: most often, to match all; to develop their abilities. Thus, everything comes down to a certain promotion of a particular leisure activity, as a way of spending leisure time. Consumption here is like a chain psychological reaction that gives a person the illusion of choice.

In addition, the struggle against alienation, the desire to find new meanings, takes on a special meaning here. Often, leisure acts as a way to find yourself. This is most clearly seen when analyzing changes in motivations.

In fact, here we can say that the leisure industry, as a service sector, captures the leisure space of people. For a certain fee, the client thus buys not only the opportunity to spend time, but also new goals and ways of self-expression. Of course, it would be wrong to reduce the data obtained to a single theory. Therefore, the motivation for coming and continuing to do some activity in the studio varies depending on gender, age and direction.

Today, leisure studios are not just a place where classes are held twice a week, but also a fairly well organized recreational space. Leisure studios are organized in such a way that a person who is engaged, who is carried away, feels that he/she belongs to a clan. Most often, the hobby develops into a form of addiction (this is noted by $79 \%$ of the surveyed students). Therefore, to the question of what values classes give you, the answers, although very diverse, are reduced to a number of basic ones. The most frequently mentioned reasons are the ability to spend free time (97\%); communication and search for new acquaintances (56\%); the ability to keep fit (13\%).

At the same time, the leisure industry sells not just services, but mood, and it is organized on this principle that leisure studios are the most successful in the market of leisure services. It is 
thanks to the sale of an atmosphere of carelessness and ease that the leisure industry becomes so popular (76\% of the responses). The usual - what is difficult in training will become easy in a battle is no longer valid here. Leisure - is not hard and not difficult, because there is an instructor who will tune in to the right wave, will not let you get bored and think that something is not working.

An important role in the leisure industry is played by the teacher, as a guide to the world of hobbies. The possibility of learning a particular activity using special programs is not slightly less, but the presence of a teacher in a special way structures the training. There is no need to force yourself to study - just come to the studio and the teacher will do it. Moreover, indeed, the tasks of the instructor are significantly expanded; he/she is now even more a sales clerk of services than a teacher is. Here, it is quite appropriate to talk about fake idleness, when the teacher is the service segment, and not the training person. That is, the task of the teacher is directly reduced to the sale of services, which should include the sale of good mood. Consequently, it is difficult to imagine the modern leisure industry without leisure studios. The leisure industry is economically profitable and useful, and the clients of leisure studios are willing to pay money not so much for training as for the time spent.

Along with this, the leisure industry is a well - organized space for communication. People often come with girlfriends and friends, which, in many ways, defuses the atmosphere of the lesson. However, the goal of the studio is to introduce people to each other, to organize the space in such a way that everyone feels involved and is the center of attention. Thus, in addition to the already formed communication spaces, that is, communication with friends and acquaintances, new ones are given rise within the studio (this fact was noted by $47 \%$ of respondents). It is interesting that here we are not talking about fleeting acquaintances, when clients collide in the hope of not meeting again. Communication takes place in a small group, and therefore it is closer. The task of leisure studios is to strengthen this communication as much as possible. At the same time, dating should be not only within the client-client framework, but also within the teacherclient. Communication within the framework of leisure studios often comes to the fore. The task of the teacher, therefore, is to ensure that each client feels as comfortable as possible. The teacher should become, if not a close friend, then the person to whom you want to come to class $(97 \%$ of respondents noted this fact). Accordingly, the sale of leisure services involves the sale of communication. The student should feel that he is not only always welcome here, but also that his/her friends are here. The established communication space extends beyond the studio. The goal of the studio is, on the one hand, to organize their leisure activities outside the studio, thus strengthening social ties and strengthening relationships with the studio; and on the other hand, not to allow the client to move to another studio, where there are more opportunities. One of the main features of the leisure industry is the opportunity for growth that is provided to customers. It should be noted that often leisure studios only form the appearance of opportunities. Often the task of the studio is to provide opportunities to customers. Most of the clients surveyed (13\%) do not participate in competitions, but the very presence of such events encourages them to study in this particular studio. In addition, most often people are not ready to participate in serious events and small internal competitions and contests on the one hand warm up interest in classes, and on the other hand do not oblige to anything serious.

The respondents are quite satisfied with the existing leisure space of the city.

\section{Discussions}

The main characteristic of leisure consumption is the freedom given to the individual in his/her free time. It is the possibility of making a choice that is the key characteristic that attracts a person so much. The possibility of individuality is contrasted with the oppressive need to follow the rules. However, when analyzing leisure consumption, it should be noted that the obligation and the possibility of choice are often very closely intertwined. The problem of distinguishing between voluntary and involuntary choice is very complex, because it is often possible to observe the interweaving of various motives, both conscious and unconscious. Unique preferences, following the laws of fashion, quickly enter the trend and, thus, acquire a mass character. Today, the need to 
identify an individual, to confirm their status, is successfully used by leisure organizers. Along with the purchase of services, leisure practices require related products. The real necessity is often replaced by an artificial status, which promises the opportunity to classify yourself as a certain consumer group or a way to express yourself to others.

Giving a playful form to the practices of consumption creates an atmosphere of seduction and charm around them. Advertisers manage to reduce life meanings to a material plan, to fetishize consumption, thanks to the creation of virtual reality images that are promoted to the market of goods. A well-designed platform for meanings can mean the success of a brand. However, modern conditions force organizations engaged in the provision of services to be mobile, ready to adapt to the consumer, try to offer not only the most popular, but also designed for a relatively narrow audience of people. Competition makes you not only actively advertise your services, but also look for a new, unique one that will become the brand of this organization and attract the attention of new consumers.

\section{Conclusions}

Today, leisure is a criterion for identifying the status of a person, and acting as a social marker of a certain lifestyle, is the sphere of manifestation of different individual capabilities. The status of consumption in the field of leisure is very pronounced here. Individuality in its original sense is far on the fringes of the leisure industry. As a distinctive feature of leisure, the refusal to work is distinguished, which is a recognized sign of reputation and status. The consumer society puts a certain imprint not only on consumption itself, but also on leisure, as the main part of it, leading to the fact that the latter is no longer so much aimed at enjoying free time as at filling with nonworking time consumption.

It is determined that leisure time for students is often aimed not so much at enjoying free time, as at filling the consumption of non-working time. The reasons why students come to leisure studios are the randomness of choice; the desire to find new meanings; the way to find yourself.

Students note the leisure industry as a sector where, for a certain fee, the client buys not only the opportunity to spend time, but also new goals and ways of self-expression.

Today, leisure studios are not just a place where classes are held twice a week, but also a fairly well organized recreational space. Leisure studios are organized in such a way that a person who is engaged in something, who is interested in something, feels that he belongs to a certain clan. The leisure industry sells not just services, but mood, and it is organized on this principle that leisure studios are the most successful in the market of leisure services.

From the point of view of students, an important role in the leisure industry is played by the teacher, as a guide to the world of hobbies. The presence of a teacher structures the training in a special way. The interviewed students are quite satisfied with the existing leisure space of the city. They note that along with the purchase of services, leisure practices require the purchase of related products. The real need for the acquisition is often replaced by an artificial status that promises the opportunity to classify yourself as a certain group of consumers or a way to declare yourself to others. It should be noted that the game form is particularly distinguished by the students, which contributes to the creation of an atmosphere of seduction and charm of the visited studio.

\section{References}

Akhiezer, A.C. (1992). Socio-cultural problems of Russia's development. Moscow: Nauka.

Baranova, A.V. (2009). Soviet consumerism. Consumption as communication-2009: materials of the 5th International Conference (pp. 36-38). St. Petersburg: Intersocis.

Bayanova, A.R., Sizova, Z.M., Chistyakov, A.A., Prokopyev, A.I., Vasbieva, D.G. (2019). A philosophical view of organizational culture policy in contemporary universities. European Journal of Science and Theology, 15(3), 121-131.

Burno, M.E. (1989). Therapy with creative self-expression. Moscow: Meditsina. 
Cherdymova. E.I. (2011). Substantiation of ecological consciousness structure for solving the problems of environmental education of the individual. Perspectives on Science, 1(16), 3537.

Cherdymova, E.I. \& Rozanova, E.V. (2018). Unregistered marriage as modern practice of students' youth family relations. EurAsian Journal of BioSciences, 12(2), 511-520.

Heidegger, M. (2003). Being and time. Kharkiv: "Folio".

Kogan, L.N. (1997). The Spiritual potential of the province yesterday and today. Sociological research, 4, 33-38.

Kuznetsova, A.A. (2007). Consumption as a text. Bulletin of the Samara State University, 5, 81-85

Lantsev, A.O. (2008). Challenges of a multicultural society: a look at the problem of identity. Modern Russia: the way to peace - the way to yourself, 1, 162-165.

Leontiev, D.A. (1999). Psychology of meaning: nature, structure and dynamics of semantic reality. Moscow: Smysl.

Levi, M. (2011). On the discussion of ecosocialism. Ecosocialist Manifesto. Moscow: Free Marxist Publishing House.

Marcuse, G. (2009). One-dimensional man. Moscow: AST.

Panarin, A. (1972). The Temptation of Globalism. Moscow: Russian National Fund.

Prudensky, G.A. (1972). Problems of working and non-working time. Moscow: Nauka.

Putilina, E.S., Cherdymova, E.I., Kurbanov, R.A., Belyalova, A.M., Shatskaya, I.I., Kobzeva, E.I., Zhuravleva, M.V. \& Meleshko, G.S. (2019). Ecological relationships in real and virtual environments: contact points. Eurasia Journal of Biosciences, 13, 1475-1487.

Radina, N.K. \& Shaidakova, N.V. (2014). On the psychology of naive anti-consumerism in the youth environment. Questions of psychology, 6, 65-74.

Reznichenko, S.M., Takhumova, O.V., Zaitseva, N.A., Larionova, A.A., Dashkova, E.V., Zotikova, O.N., \& Filatov, V.V. (2018). Methodological aspects of assessing factors affecting the sustainable development of the region. Modern journal of language teaching methods, 8(11), 70-80.

Ritzer, J. (2011). Macdonaldization of society. Moscow: Praxis.

Sartre, J.P. (2004). Being and nothing: The Experience of phenomenological Ontology. Moscow: Republic.

Shulga, M.M. (2000). Vital values in the structure of value orientations of youth. Youth and society: Materials of the scientific and practical conference. Stavropol: SSU Publishing House.

Sloterdaik, P. (2009). Critique of the Cynical mind. Yekaterinburg: U-Factoriya; Moscow: AST.

Streltsov, Yu.A. (1991). Communication in the sphere of free time. Moscow: Infra M.

Surtaev, V.Ya. (2002). Youth and art. St. Petersburg: Publishing house of St. Petersburg University.

Terekhova, O.V. (1983). The leisure industry in the USA. Moscow: Nauka.

Toro, G.D. (2014). Walden, or Life in the forest. St. Petersburg: Azbuka, AzbukaAttikus.

Veblen, T. (2010). The theory of the idle class. Moscow: Book House "LIBROCOM".

Veretekhina, S.V., Shinkareva, O.V., Kozhaev, J.P., Telepchenkova, N.V., Kuznetsova, E.A., \& Zaitseva, N.A. (2017). Evaluation methodology of the multiplier effect for the region as the result of the cluster formation. Eurasian journal of analytical chemistry, 12(5B), 533547.

Voronova, E.H. (1997). The Economy of Culture. Ryazan: Uzorochye.

Yakovleva, A.A. (2011). Consumer retretism: an alternative lifestyle in the consumer society. Journal of Sociology and Social Anthropology, 5(58), 192-201

Zinoviev, A.A. (2000). Global human anthill. Moscow: Center-polygraph. 